\title{
Penggunaan dan Penerapan Metode Pengukuran Energi dalam Upaya Penghematan Energi di Galeri Ciumbuleuit Hotel dan Apartemen Bandung
}

\author{
Delfiyanti \\ Sekolah Tinggi Pariwisata Riau \\ Jl. Pattimura No.54 Gobah Pekanbaru, email, delfiyanti.muis@ yahoo.com \\ Hp.082115709328
}

\begin{abstract}
The new index building energy performance that can allow management to follow the energy consumption for months. There are many variables that change over time during the normal routine of the day. Based on the analysis performed, the authors conclude beberpa energy management research results Galeri Ciumbuleuit Hotel and Apartment, associated with facilities and energy consumption. Initial audit methods and a detailed audit which is used for energy savings can process data over the last 3 years, and can be applied. Dibangunan energy audit method can be used to suppress the use of potential energy savings, thus saving efforts can be done better and more useful.
\end{abstract}

\section{Keywords: Method of Measurement of Energy, Energy Saving}

Cadangan energi minyak yang semakin berkurang, harga energi yang semakin meningkat menyebabkan biaya energi pun ikut meningkat. Dalam bisnis perhotelan, energi sangatlah penting, terutama dalam penggunaan energi listrik, porsi pemakaian serta alokasi dana untuk penyediaan nya adalah yang terbesar. Energi adalah suatu besaran yang secara konseptual dihubungkan dengan transformasi, proses atau perubahan yang terjadi.(Oka,A. Yoeti,2003:)

Hal ini dapat dilihat bahwa peralatan seperti lampu-lampu, lift, lemari es, laundry, pemanas, pompa-pompa, sampai pada sistem pengkondisian udara adalah beberapa alat yang dominan dalam operasional di dunia perhotelan, dan teknologi yang lebih modern seperti: elevator, Chiller, Fire Detector, Laundry equipment dan yang lainnya hampir semua menggunakan instrumen sensitif dan digital. Hotel adalah sejenis akomodasi, yang menyediakan fasilitas dan pelayanan penginapan, makan dan minum, serta jasajasa lainnya untuk umum yang tinggal untuk sementara waktu, dan dikelola secara komersial (AanSurachlanDimyati, 1998:33). Untuk mempelajari kondisi pemakaian energi dan program penghematan energi yang telah ditempuh penulis melakukan penelitian di Galeri Ciumbuleuit Hotel dan Apartemen, Jl. Ciumbuleuit no. 42.A Bandung. Usaha-usaha penghematan energi listrik belum dilaksanakan secara menyeluruh oleh pihak hotel seperti, melakukan penjadwalan operasional peralatan, penggantian lampu-lampu dengan lampu hemat energi, hal ini akan menyebabkan biaya operasional energi listrik tetap melebihi standar dari ketetapan ratio to revenue yaitu $7,8 \%$ untuk wilayah Jawa Barat berdasarkan Howarth HTL 2009 dari total pendapatan hotel sebesarRp. 42.521.360.000,-.

Data yang diperoleh selama 3 tahun sebelumnya di Galeri Ciumbuleuit Hotel dan Apartemen maka Galeri Ciumbuleuit Hotel dan Apartemen pemakaian energi nya tidak sesuai dengan standar sehingga terjadi pemborosan energi.tahun 2008, 2009 dan 2010 pemakaian energi tidak mengalami penurunan, berarti hal itu menunjukkan selama kurun waktu 3 tahun biaya energi nya cukup besar yaitu $11 \%$ sehingga terjadi pemborosan. Untuk menanggulangi masalah tersebut dilakukan efisiensi energi.

Salah satu metode yang sekarang dipakai untuk mengefisienkan pemakaian 
energi listrik adalah konservasi energi. Konservasi energi adalah peningkatan efisiensi energiyang digunakan atau proses penghematan energi. Konservasi adalah kegiatan pemanfaatan energi secara evisien dan rasional tanpa mengurangi penggunaan energi yang memang benar diperlukan untuk menunjang pembangunan nasional.(Badan Koordinasi Energi Nasional, 1983).

Dalam proses ini meliputi adanya audit energi yaitu suatu metode untuk menghitung tingkat konsumsi energi suatu gedung atau bangunan, yang mana hasilnya nanti akan dibandingkan dengan standar yang ada untuk kemudian dicari solusi penghematan konsumsi energi jika tingkat konsumsi energinya melebihi standar baku yang ada. Konsenvasi energi itu meliputi audit energi yang merupakan bagian dari manajemen. Manajemen adalah suatu proses perencanaan,

pengorganisasian, kepemimpinan, dan pengendalian upaya dari anggota organisasi serta penggunaan sumua sumber daya yang ada pada organisasi untuk mencapai tujuan organisasi yang telah ditetapkan sebelumnya (James A.F. Stoner)

$$
\text { Manajemen adalah Seni }
$$

mengkoordinasikan elemen-elemen dari faktor-faktor produksi ke arah pencapaian dari tujuan organisasi. Pencapaian sasaran organisasi terjadi melalui penggunaan manusia (men), bahan produksi (materials), dan mesin (machines). sebuah proses yang dilakukan untuk mewujudkan tujuan organisasi melalui rangkaian kegiatan berupa perencanaan, pengorganisasian, pengarahan dan pengendalian orang-orang serta sumber daya organisasi lainnya. (Nickels,McHugh and McHugh :1997)

Terdapat banyak definisi dari manajemen menurut para ahli. Manajemen adalah proses perencanaan, pengorganisasian, pengarahan, aktualisasi, dan pengawasan kegiatan/ usaha secara sistematik dan efektif oleh para anggota organisasi untuk mencapai tujuan organisasi yang telah ditetapkan. Secara sederhana, Manajemen merupakan suatu proses tindakan atau seni perencanaan, mengatur, pengarahan dan pengawasan yang dinamis yang menggerakan organisasi mencapai tujuannya

Secara umum, ada empat fungsi manajemen yang sering orang menyebutnya "POAC", yaitu Planning, Organizing, Actuating, dan Controlling. Dua fungsi yang pertama dikategorikan sebagai kegiatan mental sedangkan dua berikutnya dikategorikan sebagai kegiatan fisik. Suatu manajemen bisa dikatakan berhasil jika keempat fungsi di atas bisa dijalankan dengan baik. Kelemahan pada salah satu fungsi manajemen akan mempengaruhi manajemen secara keseluruhan dan mengakibatkan tidak tercapainya proses yang efektif dan efisien. 1. Fungsi Perencanaan (Planning)

Adalah proses yang menyangkut upaya yang dilakukan untuk mengantisipasi kecenderungan di masa yang akan datang dan penentuan strategi dan taktik yang tepat untuk mewujudkan target dan tujuan organisasi. Kegiatan dalam Fungsi Perencanaan antara lain Menetapkan pasar sasaran, Merumuskan strategi untuk mencapai pasar sasaran tersebut, Menentukan sumber-sumber daya yang diperlukan, Menetapkan standar atau indikator keberhasilan dalam pencapaian tujuan dan pasar sasaran. Strategi dan taktik dalam fungsi perencanaan dapat ditentukan dengan menggunakan metode analisis SWOT. Analisis SWOT (Strength, Weakness, Opportunity and Threat) adalah metode perencanaan strategis yang digunakan untuk mengevaluasi kekuatan, kelemahan, peluang, dan ancaman dalam suatu proyek atau suatu spekulasi bisnis.

Proses ini melibatkan penentuan tujuan yang spesifik dari spekulasi bisnis atau proyek dan mengidentifikasi faktor internal dan eksternal yang mendukung dan yang tidak dalam mencapai tujuan tersebut. Analisis SWOT dilakukan untuk mengidentifikasi kondisi internal dan eksternal yang terlibat sebagai inputan untuk perancangan proses sehingga proses yang dirancang dapat berjalan optimal, efektif, dan efisien. Namun analisis SWOT 
bisa sangat subjective. Bisa saja terjadi 2 orang menganalisa 1 perusahaan yang sama menghasilkan SWOT yang berbeda. Dengan demikian, hasil analisa SWOT hanya boleh digunakan sebagai arahan dan bukan pemecahan masalah. Pembuat analisa harus sangat realistis dalam menjabarkan kekuatan dan kelemahan internal. Kelemahan yang disembunyikan atau kekuatan yang tidak terjabarkan akan membuat arahan strategi menjadi tidak bisa digunakan.

Dalam perencanaan ada juga beberapa faktor yang harus dipertimbangkan. Yaitu harus SMART yaitu Specific artinya perencanaan harus jelas maksud maupun ruang lingkupnya. Tidak terlalu melebar dan terlalu idealis. Measurable artinya program kerja atau rencana harus dapat diukur tingkat keberhasilannya. Achievable artinya dapat dicapai. Jadi bukan anggan-angan. Realistic artinya sesuai dengan kemampuan dan sumber daya yang ada. Tidak terlalu mudah dan tidak terlalu sulit. Tapi tetap ada tantangan. Time artinya ada batas waktu yang jelas. Mingguan, bulanan, triwulan, semesteran atau tahunan. Sehingga mudah dinilai dan dievaluasi.

1. Fungsi Organisasi (Organizing)

Adalah proses yang menyangkut bagaimana strategi dan taktik yang telah dirumuskan dalam perencanaan didesain dalam sebuah struktur organisasi yang tepat dan tangguh, sistem dan lingkungan organisasi yang kondusif, dan dapat memastikan bahwa semua pihak dalam organisasi dapat bekerja secara efektif dan efisien guna pencapaian tujuan organisasi. Kegiatan dalam Fungsi Pengorganisasian antara lain Mengalokasikan sumber daya atau sarana, merumuskan dan menetapkan tugas, dan menetapkan prosedur yang diperlukan. Adanya struktur organisasi yang menunjukkan adanya garis kewenangan dan tanggungjawab, sehingga setiap pekerja akan bergerak dan bertindak sesuai dengan job description dan kewenangannya dan memiliki tanggung jawab dan bertanggung jawab atas pekerjaan yang telah dilaksanakan. Kegiatan pelatihan dan pengembangan sumber daya manusia atau tenaga kerja, hal ini sangatlah penting agar dapat menyegarkan dan menambah wawasan pekerja.

Kegiatan penempatan sumber daya manusia pada posisi yang paling tepat atau dengan kata lain strategi yang telah ditetapkan harus dilaksanakan oleh pekerja yang dinilai mampu dan layak dan memiliki pengetahuan yang cukup di bidangnya. Agar tujuan tercapai maka dibutuhkan pengorganisasian. Dalam perusahaan biasanya diwujudkan dalam bentuk bagan organisasi. Yang kemudian dipecah menjadi berbagai jabatan. Pada setiap jabatan biasanya memiliki tugas, tanggung jawab, wewenang dan uraian jabatan (Job Description). Semakin tinggi suatu jabatan biasanya semakin tinggi tugas, tanggung jawab dan wewenangnya. Biasanya juga semakin besar penghasilannya. Dengan pembagian tugas tersebut maka pekerjaan menjadi ringan. Berat sama dipikul, ringan sama dijinjing. Disinilah salah satu prinsip dari manajemen. Yaitu membagi-bagi tugas sesuai dengan keahliannya masing-masing.

\section{Implementasi (Actuating)}

$$
\text { 3. Fungsi Pengarahan dan }
$$

Adalah proses implementasi program agar dapat dijalankan oleh seluruh pihak dalam organisasi serta proses memotivasi agar semua pihak tersebut dapat menjalankan tanggungjawabnya dengan penuh kesadaran dan produktifitas yang tinggi. Kegiatan dalam Fungsi Pengarahan dan Implementasi antara lain mengimplementasikan proses kepemimpinan, pembimbingan, dan pemberian motivasi kepada tenaga kerja agar dapat bekerja secara efektif dan efisien dalam pencapaian tujuan. Memberikan tugas dan penjelasan rutin mengenai pekerjaan dan menjelaskan kebijakan yang ditetapkan. Perencanaan dan pengorganisasian yang baik kurang berarti bila tidak diikuti dengan pelaksanaan kerja. Untuk itu maka dibutuhkan kerja keras, kerja cerdas dan kerjasama. Semua sumber daya manusia yang ada harus dioptimalkan untuk mencapai visi, misi dan program kerja organisasi. Pelaksanaan kerja harus

$$
\text { p.ISSN: } 2407-800 X \quad \text { e.ISSN: 2541-4356 }
$$


sejalan dengan rencana kerja yang telah disusun. Kecuali memang ada hal-hal khusus sehingga perlu dilakukan penyesuian. Setiap SDM harus bekerja sesuai dengan tugas, fungsi dan peran, keahlian dan kompetensi masing-masing SDM untuk mencapai visi, misi dan program kerja organisasi yang telah ditetapkan.

Fungsi pengawasan dan pengendalian (controling) adalah proses yang dilakukan untuk memastikan seluruh rangkaian kegiatan yang telah direncanakan, diorganisasikan dan diimplementasikan dapat berjalan sesuai dengan target yang diharapkan sekalipun berbagai perubahan terjadi dalam lingkungan dunia bisnis yang dihadapi. Kegiatan dalam Fungsi Pengawasan dan Pengendalian antara lain , Mengevaluasi keberhasilan dalam pencapaian tujuan dan target bisnis sesuai dengan indikator yang telah ditetapkan. Hal ini harus secara rutin dilakukan supaya terlihat pada point mana target yang telah tercapai dan target yang belum tercapai sehingga dapat diambil langkah penyelesaian. Mengambil langkah klarifikasi dan koreksi atas penyimpangan yang mungkin ditemukan. Langkah ini harus selalu dilakukan agar setiap kesalahan yang ada dapat segera diperbaiki. Melakukan berbagai alternatif solusi atas berbagai masalah yang terkait dengan pencapaian tujuan dan target bisnis.

Agar pekerjaan berjalan sesuai dengan visi, misi, aturan dan program kerja maka dibutuhkan pengontrolan. Baik dalam bentuk supervisi, pengawasan, inspeksi hingga audit. Kata-kata tersebut memang memiliki makna yang berbeda, tapi yang terpenting adalah bagaimana sejak dini dapat diketahui penyimpangan-penyimpangan yang terjadi. Baik dalam tahap perencanaan, pelaksanaan maupun pengorganisasian. Sehingga dengan hal tersebut dapat segera dilakukan koreksi, antisipasi dan penyesuaian-penyesuaian sesuai dengan situasi, kondisi dan perkembangan zaman.

Dalam suatu organisasi perusahaan bisnis diharapkan mampu menguasai semua fungsi manajemen yang ada untuk mendapatkan hasil manajemen yang maksimal, tetapi di Galeri Ciumbuleuit Hotel dan Apartemen ini fungsi manajemen belum berjalan sebagai mana mestinya.

Untuk mengetahui total penggunaan energi dihotel ini hanya melihat dari total tagihan dari PLN saja, mereka tidak menggunakan metode audit energy awal maupun rinci sehingga tidak ditemukan data-data total $\mathrm{kWh}$ per room dan fasilitas lainnya. Untuk mengetahui Building energi Index dan Intensitas Konsumsi Energi suatu bangunan komersial diperlukan data total $\mathrm{kWh}$, rata-rata tingkat hunian kamar dan luas bangunan gedung. Berdasarkan informasi diataslah yang menjadi dasar pemikiran dari latar belakang masalah ini.

Dari dasar pemikiran di atas, maka penulis penting melakukan penelitian mengenai Penggunaan dan Penerapan Metode Pengkuran Energi Dalam Upaya Penghematan Energi di Galeri Ciumbuleuit Hotel dan Apartemen Bandung dengan harapan dari tesis ini dapat diketahui tingkat konsumsi energi di hotel, peluang dan solusi penghematan yang dapat direkomendasikan kepada pihak manajemen hotel. Harapan lain adanya peluang dan solusi penghematan energi sesuai kebijakan manajemen.

Manajemen dapat didefinisikan sebagai pengelolaan terhadap sumber daya manusia dan sumber daya lainnya, dengan tujuan agar secara bersama-sama dapat digunakan untuk menghadapi perubahanperubahan. (Edison Emron,2007). Definisi yang lain yaitu sebuah teknik dan fungsi manajemen untuk memonitor, merekam, menganalisis dan mengontrol aliran energi yang bekerja dalam sebuah sistem untuk mencapai efisiensi penggunaan yang maksimal. (Oka,A. Yoeti,2003).

Secara umum, ada empat fungsi manajemen yang sering orang menyebutnya "POAC", yaitu Planning, Organizing, Actuating, dan Controlling. Dua fungsi yang pertama dikategorikan sebagai kegiatan mental sedangkan dua berikutnya dikategorikan sebagai kegiatan fisik. Suatu manajemen bisa dikatakan berhasil jika

p.ISSN: $2407-800 X \quad$ e.ISSN: 2541-4356 
keempat fungsi di atas bisa dijalankan dengan baik. Kelemahan pada salah satu fungsi manajemen akan mempengaruhi manajemen secara keseluruhan dan mengakibatkan tidak tercapainya proses yang efektif dan efisien.

Dalam operasi hotel, diharapkan akan mendapatkan keuntungan (benefit) dari operasinya, untuk itu penting pula menetapkan manajemen pada engineering departemen. Dalam hal ini, proses managerial mengidentifikasi, menjelaskan, memotivasi personal dan menggambarkan hubungan antar departemen..(Edison Emron,2007).

Departemen manajer teknik dikelola untuk menyediakan pelayanan kepada tamu dan bertugas sebagai pengingat departemen lain dalam menggunakan fasilitas yang digunakan dalam tugasnya sebagai penyedia layanan, staf engineering departemen dibedakan dalam dua kategori: Fungsi Teknis (Technical functions); Berkaitan dengan fasilitas fisik gedung dan lingkungannya (building and landscaping), interior gedung, system, furniture dan peralatan.

Fungsi Manajemen (Managemen functions) Berkaitan dengan operasi departemen sebagai sebuah unit yang merupakan bagian dari struktur manajerial dalam menjalankan operasi perusahaan (merencanakan anggaran). Keberhasilan departemen ini dalam fungsi teknis adalah bergantung pada terpenuhinya performa dari fungsi manajerialnya, demikian pula performa engineering departemen akan mempengaruhi keseluruhan departemen. Departemen manajer teknik harus memiliki kemampuan untuk melaksanakan fungsi manajemen seperti perencanaan (planning), pengorganissasian

(organizing), mengarahkan (directing), pengendalian (controlling), pengaturan staff (staffing), menentukan tujuan (setting goals), memotivasi staff, mengkomunikasikan dan mengembangkan staff. Semua itu terpenuhi melalui struktur departemen yang sesuai dengan kebutuhan dan besar-kecilnya perusahaan.
Tugas dan tanggung jawab Engineering departemen, yaitu meliputi POMEC (Property Operation, Maintenance \& Energy Cost)..(Edison Emron, 2007).

PO (Property Operation).Property Operation adalah tindakan atau proses dalam melaksanakan pengoperasian secara optimum dari property hotel. Begitu juga dengan kondisi kamar yang harus selalu siap pakai seperti catnya yang baik, tidak belang dan tidak mengelupas termasuk juga bagaimana agar boiler tetap beroperasi menghasilkan air hangat dengan suhu yang stabil ke kamar-kamar.

M (Maintenance). Maintenance atau pemeliharaan adalah suatu proses mempertahankan atau mengembalikan kondisi peralatan atau property hotel sesuai spe-sifikasi standar atau yang sudah ditetapkan. Dengan demikian sesuatu yang mendapatkan pemeliharaan yang dilakukan dengan baik diharapkan akan terhindar dari kerusakan-kerusakan yang tidak terduga atau suatu gejala kerusakan dapat tedeteksi sedini mungkin.

EC (Energy Cost). Biaya energi pada hotel adalah biaya yang dikeluarkan untuk mendapatkan energi yang dipergunakan untuk mendukung suatu aktivitas pekerjaan dalam hotel. Biaya energi menjadi tanggung jawab engineering departemen adalah Bahan bakar minyak atau gas untuk keperluan hotel secara keseluruhan, tetapi tidak termasuk untuk keperluan kitchen. Bahan bakar minyak atau gas untuk keperluan kitchen merupakan biaya dari kitchen itu sendiri. Selain itu, air untuk keperluan hotel secara keseluruhan, termasuk juga oli untuk generator dan AC juga merupakan biaya energi yang terpusat di engineering..(Edison Emron,2007).

Usaha-usaha untuk menghemat energi di segala bidang makin dirasakan perlu karena semakin terbatasnya sumber-sumber energi yang tersedia dan semakin mahalnya biaya pemakaian energi. Usaha-usaha penghematan energi pada suatu bangunan komersial seperti hotel atau suatu pabrik hanya dapat dilakukan jika telah diketahui 
untuk apa energi tersebut digunakan dan berapa besarnya pemakaian energi di tiaptiap bangunan gedung hotel atau pabrik tersebut.

Untuk mengetahui hal tersebut maka diperlukan pengetahuan tentanga udit energi atau keseimbangan energi. Berdasarkan kegiatan yang dilakukan pada akhirnya audit energi didefinisikan sebagai kegiatan untuk mengidentifikasi jenis energi dan mengidentifikasikan besarnya energi yang digunakan pada bagian-bagian operasi suatu industri/pabrik atau bangunan serta mencoba mengidentifikasi kemungkinan penghematan energi. Audit energi dapat dilakukan setiap saat atau sesuai dengan jadwal yang sudah ditetapkan. Monitoring pemakaian energi secara teratur merupakan keharusan untuk mengetahui besarnya energi yang digunakan pada setiap bagian operasi selama selang waktu tertentu. Dengan demikian usahausaha penghematan dapat dilakukan. (Abdurarachim, 2002).

Sebagaimana yang disarankan Departemen Pertambangan dan Energi, metode audit energi pada bangunan gedung pada intinya terdiri dari dua bagian, yaitu: audit energi awal dan audit energi rinci. Pelaksanaan audit awal dan audit rinci adalah sebagai berikut:

Kegiatan audit energi awal meliputi: Pengumpulan data energi bangunan dengan data-data historis yang tersedia dan tidak memerlukan pengukuran. Data-data yang diperlukan pada audit energi awal meliputi:

Dokumentasi bangunan yang dibutuhkan adalah gambar teknik bangunan sesuai pelaksanaan konstruksi terdiri dari:

a. Denah bangunan gedung.

b. Denah instalasi pencahayaan bangunan.

c. Diagram satu garis listrik, lengkap dengan penjelasan penggunaan daya listriknya dan besarnya sambungan daya dari PLN serta besarnya daya listrik cadangan dari Diesel Generating Set (Genset).

Pembayaran rekening listrik bulanan bangunan gedung selama satutahun terakhir.Tingkat hunian bangunan (occupancy rate).
Menghitung besarnya Intensitas
Konsumsi Energi (IKE) gedung. Berdasarkan data bangunan dan data energi seperti disebutkan di atas dapat dihitung: Rincian luas bangunan dan luas total bangunan gedung $\left(\mathrm{m}^{2}\right)$; Konsumsi energi bangunan gedung per tahun ( $\mathrm{kWh} /$ tahun); Intensitas Konsumsi Energi (IKE) bangunan gedung per tahun $\left(\mathrm{kWh} / \mathrm{m}^{2}\right.$.tahun); Biaya energi bangunan gedung $(\mathrm{Rp} / \mathrm{kWh})$.

Intensitas Konsumsi Energi (IKE) listrik merupakan istilah yang digunakan untuk mengetahui besarnya pemakaian energi pada suatu sistem (bangunan). Namun energi yang dimaksudkan dalam hal ini adalah energi listrik. Pada hakekatnya Intensitas Konsumsi Energi ini adalah hasil bagi antara konsumsi energi total selama periode tertentu (satu tahun) dengan luasan bangunan. Satuan IKE adalah $\mathrm{kWH} / \mathrm{m} 2$ per tahun.

Nilai intensitas konsumsi energi penting untuk dijadikan sebagai tolak ukur seberapa besar potensi efisiensi energi yang mungkin diterapkan di tiap ruangan atau seluruh area hotel.Dengan membandingkan intensitas konsumsi energi hotel dengan standar nasional, dapat diketahui apakah sebuah ruangan atau keseluruhan hotel sudah efisien.

\section{METODE}

Jenis penelitian ini adalah penelitian kuantitatif dengan pendekatan deskriptif analisis yang menggunakan metode evaluasi dan studi literature serta dilakukan konservasi energi. Digunakan untuk membuktikan dan memperkuat suatu penelitian sehingga penelitian tersebut dapat dipertanggung jawabkan. Teknik pengumpulan data mempunyai arti semua bentuk penerimaan data yang dilakukan dengan cara merekam kejadian, menghitungnya, mengukurnya, dan mencatatnya.

\section{HASIL}

Galeri Ciumbuleuit Hotel \& Apartmen terletak dikawasan Bandung Utara di jalan 
Ciumbuleuit no.42 Bandung.Galeri Ciumbuleuit Hotel \& Apartmen di bangun pada tanggal 1 April 2004 dan selesai pada tanggal 20 April 2005. Galeri Ciumbuleuit Hotel \&Apartmen memiliki total lantai sebanyak 18 lantai mulai dari 5 sampai 26 (kecuali 13, 14, 23, 24), satu lantai lobby serta 5 lantai basement.

Hasil penelitian dapat diperoleh besarnya IKE listrik per satuan luas yang dikondisikan tahun 2009 adalah 14,28 $\mathrm{kWh} / \mathrm{m}^{2} /$ bulan dan untuk tahun 2008 adalah 16,95. Bila dibandingkan dengan intensitas konsumsi energi untuk bangunan komersial, maka IKE Galeri Ciumbeleuit Hotel dan Apartemen dapat dikatakan masuk dalam kategori cenderung tidak efisien yang artinya Galeri Ciumbuleuit Hotel dan Apartemen Bandung mengkonsumsi energi listrik yang kuat atau cenderung tidak efisien.

\section{PEMBAHASAN}

Agar pekerjaan berjalan sesuai dengan visi, misi, aturan dan program kerja maka dibutuhkan manajemen yang fungsi nya adalah "POAC", yaitu Planning, Organizing, Actuating, dan Controlling. Baik dalam bentuk supervisi, pengawasan, inspeksi hingga audit. Kata-kata tersebut memang memiliki makna yang berbeda, tapi yang terpenting adalah bagaimana sejak dini dapat diketahui penyimpanganpenyimpangan yang terjadi. Baik dalam tahap perencanaan, pelaksanaan maupun pengorganisasian. Sehingga dengan hal tersebut dapat segera dilakukan koreksi, antisipasi dan penyesuaian-penyesuaian sesuai dengan situasi, kondisi dan perkembangan zaman.

Manajemen menurut para ahli. Manajemen adalah proses perencanaan, pengorganisasian, pengarahan, aktualisasi, dan pengawasan kegiatan/ usaha secara sistematik dan efektif oleh para anggota organisasi untuk mencapai tujuan organisasi yang telah ditetapkan. Secara sederhana, Manajemen merupakan suatu proses tindakan atau seni perencanaan, mengatur, pengarahan dan pengawasan yang dinamis yang menggerakan organisasi mencapai tujuannya.
Dua fungsi yang pertama dari manajemen dikategorikan sebagai kegiatan mental sedangkan dua berikutnya dikategorikan sebagai kegiatan fisik. Suatu manajemen bisa dikatakan berhasil jika keempat fungsi di atas bisa dijalankan dengan baik. Kelemahan pada salah satu fungsi manajemen akan mempengaruhi manajemen secara keseluruhan dan mengakibatkan tidak tercapainya proses yang efektif dan efisien.

Dalam suatu organisasi perusahaan bisnis diharapkan mampu menguasai semua fungsi manajemen yang ada untuk mendapatkan hasil manajemen yang maksimal, tetapi di Galeri Ciumbuleuit Hotel dan Apartemen ini fungsi manajemen belum berjalan sebagai mana mestinya.

Dalam matrik manajemen energi kebijakan energi baru terlaksana pada tingkatan level 1 yaitu hanya sebatas tertulis set garis panduan dan tanggung jawab informasi sesuai batas waktu dalam pengorganisasian nya. Untuk menjalankan penghematan energi motivasi dapat dilaksanakan dengan cara memberi beberapa penghargaan staf pentingnya penghematan energi. Sistim informasi bekerja memeriksa faktur tagihan pemakaian energi, dan dalam pemasarannya mempromosikan efisiensi energi. Untuk investasi hanya mengukur biaya terendah yang diambil untuk panduan pembelian dan pemeliharaan peralatan.

Dari hasil penelitian diatas diketahui bahwa tahun 2008, 2009 dan 2010 pemakaian energi tidak mengalami penurunan, berarti hal itu menunjukkan selama kurun waktu 3 tahun biaya energinya cukup besar yaitu $11 \%$ sehingga terjadi pemborosan. Distribusi konsumsi tertinggi adala $45 \%$ yang terdapat pada AC dan Pendinginan, pencahayaan $15 \%$, lift $5 \%$, Cleaning dan Loundry $2 \%$.

Menggunakan indeks yang normal data dalam hubungan suhu dapat mungkin untuk membandingkan jumlah energi yang digunakan dalam bulan panas dengan nilai pada bulan dingin tanpa keprihatinan suhu. Manajemen dapat mengontrol beberapa variabel lain, seperti jumlah pengguna di

p.ISSN: $2407-800 X \quad$ e.ISSN: 2541-4356 
dalam gedung dan seterusnya dan kemudian meningkatkan kualitas kerja. Simulasi dan aktual data menunjukkan bahwa indeks menyajikan yang baik peningkatan analisis. Berdasarkan analisis yang telah dilakukan maka penulis menyimpulkan beberpa hasil penelitian manajemen energi Galeri Ciumbuleuit Hotel dan Apartemen, terkait dengan fasilitas dan konsumsi energi.

Metode audit energi dapat mengukur total energi keseluruhan di Galeri Ciumbuleuit Hotel dan Apartemen sebesar $11 \%$, atau dengan kata lain penggunaan energi terbilang boros dibandingkan dengan ketetapan ratio to revenue yaitu $7,8 \%$ untuk wilayah Jawa Barat berdasarkan Howarth HTL 2010 dari total pendapatan hotel sebesar Rp. 42.521.360.000,-. Berdasarkan hasil perhitungan dan Building Energi Index (BEI) dimana konsumsi energi terbesar adalah untuk konsumsi energi listrik, dimana $\mathrm{kWh}$ total sebesar 3.930.198 dengan Occupancy Rate $66,53 \%$ sedangkan luas bangunan sebesar 19,511,53 $\mathrm{m}^{2}$, didapatkan Building Energi Index sebesar 302,765 $\mathrm{kWh} / \mathrm{m}^{2} /$ tahun.

Dari hasil tersebut jika menggunakan parameter untuk bangunan komersial maka Building Energi Index Galeri Ciumbuleuit Hotel dan Apartemen masuk dalam kategori En.Intensive Build yang artinya terjadinya pemborosan dengan kata lain pemakaian energi listrik yang kuat atau cendrung tidak efisien. Intensitan Konsumsi Energi per satuan luas yang dikondisikan adalah 16,78 $\mathrm{kWh} / \mathrm{m}^{2} /$ bulan, maka jika kita mengacu kepada tabel Intensitas Konsumsi Energi untuk bangunan komersial , maka IKE Galeri Ciumbuleuit Hotel dan Apartemen masuk dalam kategori "cendrung tidak efisien" yang artinya terjadinya pemborosan dalam mengkonsumsi energi.

Metode audit energi dapat diterapkan di Galeri Ciumbuleuit Hotel dan Apartemen walaupun belum memiliki program efisiensi energi sehingga staf yang ada belum memahami bagaimana cara manajemen energi. Dan tidak memiliki data pemakaian energi sehingga sulit untuk menghitung laporan pemakaian energi per minggu atau Jurnal Daya Saing per bulan bahkan per tahunnya, sehingga energi tidak bisa dikontrol maupun dianggarkan. Setelah dilakukan penelitian dan penulis dapat merekomendasikan metode audit energi untuk dapat diterapkan dalam upaya penghematan energi yang mana pada penyelenggaraannya dapat dievaluasi dan dapat di implementasikan.

Hasil data audit energi dapat dijadikan dasar kebijakan bagi manajemen untuk melakukan konservasi energi. Salah satu efisiensi energi yang harus dilakukan adalah dengan mengatur temperatur $\mathrm{AC}$ seperti standar temperatur $22-25^{\circ} \mathrm{C}$ untuk public area dan $18-20^{\circ} \mathrm{C}$ untuk ruangan. Untuk wilayah Jawa Barat dan sekitarnya terutama di kota Bandung khusus nya di Galeri Ciumbuleuit Hotel dan Apartemen potensi penghematan yang dapat dilakukan pada $\mathrm{AC}$ adalah merubah temperature $\mathrm{AC}$ menjadi $26-29^{\circ} \mathrm{C}$ untuk public area dan 21 - $24^{0} \mathrm{C}$ untuk didalam ruangan. Jadi untuk $1^{0} \mathrm{C}$ harga nya adalah Rp.265.392/hari berarti kalau 1 bulan $1^{0} \mathrm{C}$ harganya Rp.7.961.760,- dan dalam satu tahun terjadi penghematan Rp.95.541.120 untuk $1^{0} \mathrm{C}$ temperatur AC. Dalam penelitian ini penghematan pada $\mathrm{AC}$ adalah dilakukan perubahan temperatur $22-25^{0} \mathrm{C}$ menjadi $26-29^{0} \mathrm{C}$, untuk public area terdapat $3^{\circ} \mathrm{C}$ perubahan temperatur, ini berarti terdapat penghematan sebesar Rp.95.541.120,dalam waktu 1 tahun/ 1 pk AC. Begitu juga untuk pemakaian $\mathrm{AC}$ dalam ruangan.

Kurangi menggunakan lampu pijar, lampu sorot yang memiliki jumlah watt yang tinggi sehingga terjadi pemborosan watt lampu pakai lah lampu hemat energi seperti PLC. Untuk penghematan lampu payback periodnya ditahun ke- 2 dengan IRR nya $30 \%$. Dengan menggunakan analisis ekonomi IRR investasi lampu sebesar Rp. 23.478.600,- per 5 tahun. Hasil penelitian diketahui bahwa tahun 2008, 2009 dan 2010 pemakaian energi tidak mengalami penurunan, berarti hal itu menunjukkan selama kurun waktu 3 tahun biaya energinya cukup besar yaitu $11 \%$ sehingga terjadi pemborosan. Dengan demikian data tersebut dapat menjawab

p.ISSN: $2407-800 X \quad$ e.ISSN: 2541-4356 
hipotesis bahwa metode audit awal dan audit rinci yang digunakan untuk penghematan energi dapat mengolah data selama 3 tahun terakhir, dan bisa diaplikasikan.

Metode audit energi dibangunan dapat dijadikan untuk menekan penggunaan energi dari potensi penghematannya, sehingga upaya-upaya penghematan dapat dilakukan dengan lebih baik dan berguna.

\section{SIMPULAN}

Galeri Ciumbuleuit Hotel dan Apartemen memiliki program efisiensi energi yang berkelanjutan dengan melibatkan seluruh staf maupun tamu, sehingga dapat meminimalisir konsumsi energi. Galeri Ciumbuleuit Hotel dan Apartemen harus memiliki data yang lengkap mengenai konsumsi energi listrik,air, solar maupun gas sehingga dapat dijadikan sebagai laporan perbandingan pemakaian energi per minggu, bulan atau tahun supaya energi dapat di kontrol dan dianggarkan, serta dapat diadikan dasar kebijakan manajemen untuk melakaukan konservasi energi.

\section{DAFTAR RUJUKAN}

Abdul Rachman Arief. 2005. Pengantar Ilmu Perhotelan dan Restoran. Yogyakarta : Graha Ilmu.

Arikunto Suharsimi. 2006. Prosedur Penelitian, Cetakan keenambelas, Jakarta : Rineka Cipta

Anoymus. 2001. Energy Management and Conservation Guide. Washington : American Hotel and Lodging Foundation.

Anoymus. 2006. Metode Audit Energi dan Implementasi. Malang: Jurusan Teknik Elektro, Universitas Barawijaya.

Andre Hernowo. 2010. Akutansi Manajemen, Bandung: STP Bandung.
Bagyono. 2007. Pariwisata dan Perhotelan, Cetakan Kedua , Bandung : Alfabeta.

Damardjati. 1995. Istilah-istilah Dunia Pariwisata. Jakarta: Pradnya Paramita.

Direktorat Jenderal Pengembangan Energi. 1992. Petunjuk Teknis Konservasi Energi; Prosedur Audit Energi Pada Bangunan Gedung. Jakarta : Departemen Pertambangan dan Energi.

Edison, Emron. 2007. Profesional Hotel Engineering, Bandung: Alfabeta.

Haifa Wahyu. 2010. Manajemen Energi dan Fasilitas Hotel. Bandung: STP Bandung.

Haifa wahyu, dan Tim. 2010. kutipan tugas kelompok mata kuliah Manajemen Energi dan Fasilitas Hotel. STP Bandung.

Indonesia Hotel Industry. 2009. Howarth HTL

Isril Haen. 2010. Manajemen Energi dan Fasilitas Hotel. Bandung: STP Bandung.

Marpaung Happy dan Bahar Herman. 2002. Pengantar Pariwisata, Bandung: Alfabeta.

Nyoman S. Pendit, 2003, Ilmu Pariwisata. Jakrta: Pradnya Paramita.

Oka A. Yoeti, 1996, Pengantar Pariwisata. Bandung : Angkasa.

Oka A. Yoeti, 2003, Hotel Engineering, Jakarta : PT.Perca.

Rizka Elyza, dkk. 2005. Buku Panduan Efisiensi Energi di Hotel. Jakarta : Pelangi, www.pelangi.or.id

p.ISSN: $2407-800 X \quad$ e.ISSN: 2541-4356 
Simatupang Violetta. 2009. Pengaturan Hukum Kepariwisataan Indonesia. Bandung: PT.Alumni.

Sulastiyono, Agus. 2005. Managemen Penyelenggaraan Hotel, Cetakan keduabelas, EdisiPertama, Bandung: Alfabeta.

SNI 03-6196-2000. Prosedur Audit Energi Pada Bangunan Gedung.

Wisnu HS Al Bataafi. 2006. Housekeeping Departement Flour and Public Area. Bandung : Alfabeta. 